(c) American Dairy Science Association, 2005.

\title{
Changing Definition of Productive Life in US Holsteins: Effect on Genetic Correlations
}

\author{
S. Tsuruta, ${ }^{1}$ I. Misztal, ${ }^{1}$ and T. J. Lawlor ${ }^{2}$ \\ ${ }^{1}$ Animal and Dairy Science Department, University of Georgia, Athens 30602 \\ ${ }^{2}$ Holstein Association USA Inc., Brattleboro, VT 05301
}

\begin{abstract}
Data included 392,800 records for cows born between 1995 and 1997. Traits analyzed were milk, fat, and protein yields, somatic cell score, days open (DO), 18 linear type traits, final score, and several measures of longevity. Productive life (PL) was defined as the total number of days in milk up to 84 mo of age with a restriction of 305,500 , or $999 \mathrm{~d}$ per lactation $\left(\mathrm{PL}_{305}\right.$, $\mathrm{PL}_{500}$, or $\mathrm{PL}_{999}$, respectively). Herd life was defined as the total number of days from the first calving date to the last (culling) date. A multiple-trait sire model including the effects of registration status, herd-year, age group, month of calving and stage of lactation, sire, and residual was used for parameter estimation. The average duration of the first lactation was $365 \mathrm{~d}$ for survivors and $386 \mathrm{~d}$ for culled cows. Lactation lengths for the survivors in the next 3 parities all exceeded 330 d. Heritability estimates of between 0.08 and 0.10 were obtained for all definitions of longevity. As maximum recordable PL was increased from 305 to 999 d per lactation, the genetic correlations with milk production increased (from -0.11 to +0.14 ) and with DO decreased $(-0.62$ to -0.27$)$. Formulas for an indirect prediction of PL from correlated traits were developed. As maximum PL per lactation was increased, little change in the weights used to predict the various measures of PL, with the exception of DO was found. As the currently used value of $\mathrm{PL}_{305}$ does not properly account for the longer lactation lengths that are routinely occurring with today's cows, PL with longer lactations may be preferable in routine evaluation.
\end{abstract}

(Key words: genetic correlation, lactation length, longevity, productive life)

Abbreviation key: DO = days open, $\mathbf{H L}=$ herd life, $\mathbf{P L}=$ productive life.

\section{INTRODUCTION}

A long productive life (PL) is a desirable trait from several different perspectives. Longevity combines all

Received September 3, 2004.

Accepted November 24, 2004.

Corresponding author: Shogo Tsuruta; e-mail: shogo@uga.edu. of the characteristics that are directly associated with a cow's ability to successfully stay in the herd. No assumptions are required regarding the incidence of different health traits or the economic importance of any trait. No distinction is made between traits that are associated with involuntary or voluntary culling. They are all cumulatively rolled up into one simple measurement, when the cow is culled.

However, a complication with measuring the longevity of dairy cows is that the dairy production system is in a constant state of flux. Traits values that were perfectly acceptable at one time may later become a limiting factor. For example, the improvement in the genetic merit of dairy cows for production is being accompanied by deterioration in fertility. New technology, (e.g., bST) can change the lactation curve. Health issues, such as metritis, ketosis, or lameness, can change in incidence from being a minor to a major problem. Variable costs, such as feed and labor, can lead to important changes in how cows are managed. Therefore, PL should be considered more like a snapshot of the risk factors associated with culling rather than a definitive trait with a fixed definition that will provide steady, long-lasting associations with other traits, inasmuch as it is difficult to predict an optimal definition of PL in the future when genetic correlations of PL with other traits change over time.

When genetic evaluations for PL were first introduced in 1994, production records beyond 305 DIM were not available to the Animal Improvement Programs Laboratory of USDA; nor did the industry have access to any genetic information on reproduction. The current definition of PL is the total number of DIM with a limit of 305 DIM per lactation at 84 mo of age for US Holsteins (VanRaden and Klaaskate, 1993). Since the introduction of the PL evaluations, several factors, such as duration of the lactations, culling rates across lactations and the age distribution of the herds, may have changed. This study investigated whether previous assumptions are still applicable under today's conditions.

Many countries include some measure of longevity in their national breeding objectives (VanRaden, 2002). Because culling decisions are not made until several months or years into a cow's life, early predictions of 
PL are necessary to obtain an evaluation on young bulls and cows. Genetic evaluation of PL in Holsteins is obtained by combining direct PTA for PL along with an indirect prediction of PTA for PL from correlated traits (Weigel et al., 1998; VanRaden, 2001). Weigel et al. (1998) calculated genetic correlations of PL with type and production traits for bulls born up to 1983. Lawlor et al. (2002) and Tsuruta et al. (2004) calculated genetic correlations using data on younger animals and a model where genetic correlations were assumed as functions of year of birth. The correlations they obtained were mostly lower in magnitude than those by Weigel et al. (1998) and changed with time. The largest change in correlations was for fat yield from 0.21 (1983) to -0.08 (1993). The changes were larger than what would be expected by changes in selection intensity or breeding goals (Lawlor et al., 2002). One possibility is that many of these changes were directly related to restricting the measurement of the productive period to only 305 DIM per lactation. When almost all the cows have lactations $>305 \mathrm{~d}$, PL becomes a parity count.

The goals of this study were to estimate genetic parameters for PL for several definitions of PL using recent data, and to update equations for obtaining an early prediction of a cow's PL.

\section{MATERIALS AND METHODS}

\section{Data}

A data file for production traits (305-d milk, fat, and protein yields), SCS, days open (DO), and DIM was provided by Animal Improvement Programs Laboratory-USDA, and another data file for 18 linear type traits and final scores was obtained from the Holstein Association USA, Inc. (Brattleboro, VT). Days open was calculated by the USDA based on the presentation of VanRaden et al. (2003) (i.e., for lactations with no reported services, $\mathrm{DO}=$ calving interval - mean gestation length ( $280 \mathrm{~d}$ ); for lactations with no next calving date, DO = last service date - current calving date). Records of cows born between 1995 and 1997 were extracted from both files and merged. Cows born after 1997 were not used to avoid censored records for PL. The data set comprised 392,800 records with 17,345 sires including 3 generations. Means and standard deviations for the variables analyzed are presented in Table 1. Several studies have proposed that longevity traits such as functional PL or herd life (HL) adjusted for milk production should be used to account for voluntary culling on milk (Hudson and Van Vleck, 1981; Ducrocq et al., 1988; Allaire and Gibson, 1992; Boldman et al., 1992; Dekkers et al., 1994). However, our preliminary analysis indicated that no significant differences existed between genetic correlations of PL with other traits estimated
Table 1. Means and standard deviations for the different traits.

\begin{tabular}{|c|c|c|}
\hline Trait $^{1}$ & Mean & SD \\
\hline Milk, kg & 11,374 & 1916 \\
\hline Fat, kg & 414 & 74 \\
\hline Protein, kg & 338 & 54 \\
\hline SCS & 3.0 & 1.4 \\
\hline Days open, d & 144 & 67 \\
\hline Stature & 27.1 & 8.2 \\
\hline Strength & 21.9 & 7.4 \\
\hline Body depth & 22.0 & 7.1 \\
\hline Dairy form & 23.5 & 7.0 \\
\hline Rump angle & 25.8 & 8.6 \\
\hline Thurl width & 22.8 & 7.3 \\
\hline Rear legs side view & 26.9 & 8.3 \\
\hline Foot angle & 22.0 & 8.4 \\
\hline Fore udder attachment & 22.3 & 8.3 \\
\hline Rear udder height & 24.4 & 8.3 \\
\hline Rear udder width & 23.3 & 7.7 \\
\hline Udder cleft & 27.9 & 7.6 \\
\hline Udder depth & 31.0 & 8.2 \\
\hline Front teat placement & 25.0 & 8.6 \\
\hline Teat length & 21.9 & 7.8 \\
\hline Rear legs rear view & 22.9 & 8.8 \\
\hline Udder tilt & 28.4 & 7.7 \\
\hline BCS & 24.6 & 6.4 \\
\hline Final score & 76.5 & 5.7 \\
\hline $\mathrm{PL}_{305}$, DIM per lactation & 274 & 67 \\
\hline $\mathrm{PL}_{500}$, DIM per lactation & 325 & 108 \\
\hline $\mathrm{PL}_{999}$, DIM per lactation & 332 & 123 \\
\hline HL, DIM per lactation & 332 & 123 \\
\hline $\mathrm{PL}_{305}$, lifetime DIM & 729 & 321 \\
\hline $\mathrm{PL}_{500}$, lifetime DIM & 864 & 372 \\
\hline $\mathrm{PL}_{999}$, lifetime DIM & 881 & 377 \\
\hline HL, lifetime days & 1042 & 511 \\
\hline
\end{tabular}

${ }^{1} \mathrm{PL}_{305}=$ Productive life with restriction of $305 \mathrm{~d}$ per lactation; $\mathrm{PL}_{500}=$ productive life with restriction of $500 \mathrm{~d}$ per lactation; $\mathrm{PL}_{999}=$ productive life with restriction of $999 \mathrm{~d}$ per lactation; $\mathrm{HL}=$ herd life.

using true unadjusted PL and functional PL adjusted with linear and quadratic regressions for milk yield, suggesting that low milk production may not be a primary reason for voluntary culling. Therefore, to simplify the interpretation of results, the PL was not adjusted for any traits in this study.

\section{Definition of Longevity}

In this study, 4 ways of measuring PL were investigated. The first 3 ways $\left(\mathrm{PL}_{305}, \mathrm{PL}_{500}\right.$, or $\left.\mathrm{PL}_{999}\right)$ were defined as the total days of lactation (using test-day information) up to 84 mo of age with restrictions of $\leq 305$, 500 , or 999 d per lactation, respectively. The fourth measure was called HL, which was defined as the total days from the first calving date to the last (culling) date (i.e., including dry periods). For each longevity trait (i.e., $\mathrm{PL}_{305}$, $\mathrm{PL}_{500}$, $\mathrm{PL}_{999}$, or HL), a multiple-trait analysis with 24 other traits was conducted.

\section{Model}

The following multiple trait sire model was used: 


$$
\mathbf{y}=\mathbf{X} \boldsymbol{\beta}+\mathbf{Z u}+\mathbf{e}
$$

where $\mathbf{y}=$ vectors of observations for 25 traits (PL, milk, fat, protein, SCS, DO, 18 linear type traits, and final score); $\boldsymbol{\beta}=$ vectors of effects for registration status (registered or grade), herd-year, age group, month of calving, and stage of lactation $\times$ year at classification (type traits only); $\mathbf{u}=$ vectors of sire effects; $\mathbf{e}=$ vectors of residual effects; and $\mathbf{X}$ and $\mathbf{Z}=$ incidence matrices for corresponding effects. The variances were defined as:

$$
\mathrm{V}=\operatorname{Var}\left[\begin{array}{l}
\mathbf{u} \\
\mathbf{e}
\end{array}\right]=\left[\begin{array}{cc}
\mathbf{G} \otimes \mathbf{A}_{\mathrm{n}} & 0 \\
0 & \mathbf{R} \otimes \mathbf{I}
\end{array}\right]
$$

where $\mathbf{G}=$ a $25 \times 25$ sire (co)variance matrix for 25 traits; $\otimes=$ the direct matrix product; $\mathbf{A}_{\mathrm{n}}=$ the additive genetic relationship matrix for $\mathrm{n}$ sires; $\mathbf{R}=$ a $25 \times 25$ residual variance matrix for 25 traits; and $\mathbf{I}=$ the identity matrix. Variance components were estimated with GIBBS2F90 (Misztal et al., 2002), which is a Fortran 90 program using a Bayesian approach via the Gibbs sampling algorithm. After 10,000 Gibbs samples were discarded as burn-in, 50,000 samples were used to calculate posterior means and standard deviations for (co)variance components, heritabilities, and correlations.

\section{Weights and Maximum Reliability}

For indirect PTA of PL, weights or partial regressions of $\mathrm{PL}$ on genetically correlated traits were calculated as follows:

$$
\mathbf{w}=\operatorname{Cov}\left(\mathbf{u}_{\mathrm{PL}}, \mathbf{U}\right)^{\prime} \operatorname{Var}(\mathbf{U})^{-1}
$$

where $\mathbf{u}_{\mathrm{PL}}=$ a vector of sire effects for PL, and $\mathbf{U}=\mathrm{a}$ matrix of sire effects for other traits. Using the (co)variance matrix:

$$
\mathbf{G}=\left[\begin{array}{cc}
\mathbf{G}_{\mathrm{PL}, \mathrm{PL}} & \mathbf{G}_{\mathrm{PL}, \mathrm{j}} \\
\mathbf{G}_{\mathrm{j}, \mathrm{PL}} & \mathbf{G}_{\mathrm{i}, \mathrm{j}}
\end{array}\right]
$$

the formula for the weight can be written as

$$
\mathbf{w}=\mathbf{G}_{\mathrm{PL}, \mathrm{j}} \mathbf{G}_{\mathrm{i}, \mathrm{j}}^{-1}
$$

where $\mathbf{G}_{\mathrm{PL}, \mathrm{PL}}=$ the genetic variance for PL; $\mathbf{G}_{\mathrm{PL}, \mathrm{j}}$ and $\mathbf{G}_{\mathrm{j}, \mathrm{PL}}=$ the genetic covariances between PL and other traits; and $\mathbf{G}_{\mathrm{i}, \mathrm{j}}=$ the genetic (co)variance for other traits. These weights were calculated using standardized traits (divided by standard deviation of each trait) to be able to compare among traits. Maximum reliabilities for the indirect PTA of PL were calculated as Boldman et al. (1992) described:

$$
\begin{gathered}
\mathbf{r}^{2}=\operatorname{Cov}\left(\mathbf{u}_{\mathrm{PL}}, \mathbf{U}\right)^{\prime} \operatorname{Var}(\mathbf{U})^{-1} \operatorname{Cov}\left(\mathbf{u}_{\mathrm{PL}}, \mathbf{U}\right)^{\prime} \operatorname{Var}\left(\mathbf{u}_{\mathrm{PL}}\right)^{-1} \\
=\mathbf{G}_{\mathrm{PL}, \mathrm{j}} \mathbf{G}_{\mathrm{i}, \mathrm{j}}^{-1} \mathbf{G}_{\mathrm{PL}, \mathrm{j}} \mathbf{G}_{\mathrm{PL}, \mathrm{PL}}^{-1}
\end{gathered}
$$

The maximum reliability is an upper limit to the reliability of indirect PL, assuming that sire effects for other traits are known with no error. The largest value among those maximum reliabilities for all combinations can be determined to select optimum traits for the indirect prediction of PL.

\section{RESULTS AND DISCUSSION}

\section{Culling Rates and Lactation Length}

Culling rate was small in the first parity, but greater than $50 \%$ in the third parity, and increased to $>95 \%$ in the fifth parity (Table 2). Over the past $20 \mathrm{yr}$, the age distribution of US Holsteins has shifted towards younger ages, relative to a study by Nieuwhof et al. (1989). One of the consequences of this change is that there are now fewer potential replacements per cow. The cows in this study had 2.8 parities on average, compared with 3.4 parities 20 yr ago (Nieuwhof et al., 1989). The current numbers are also underestimated somewhat, as the cows in this study are only those of $\leq 84$ mo of age.

According to the USDA, the average phenotypic difference in milk production of a cow born in $1975 \mathrm{vs}$. 1995 is $3323 \mathrm{~kg}$ (http://aipl.arsusda.gov/dynamic/trend/ current/trndx.html). Similar differences in parity distribution over time can be observed in today's herds when categorized by production. Smith et al. (2002) summarized data from herds whose records were processed at the Dairy Records Management Systems in Raleigh, NC. The results from the current study were more similar to those of Smith et al. (2002) than to those of Nieuwhof et al. (1989). For all regions analyzed, a frequency of first-lactation cows was higher and a frequency of third- and later-lactation cows was lower as production levels increased. Van Arendonk (1985) showed that the optimum length of HL was $42.9 \mathrm{mo}$, which is much longer than the mean HL (34.3 mo) observed in this study, and that high-producing herds had shorter optimum HL, mainly through increased voluntary replacement due to management decisions.

Culling rates have also changed dramatically (Table 3 ) in the past $20 \mathrm{yr}$. Previously, the risk of being culled rose gradually with each successive lactation (Nieuwhof et al., 1989). In this study, the risk of being culled started low (17\%) within the first lactation, rose rapidly over the next 2 lactations (35 and $47 \%$, respectively), and then dramatically increased to the point (71\%) where very few cows remained after 5 lactations. Culling rates increased quickly after the first lactation and 
Table 2. Number of records, means, and standard deviations of DIM for all cows, culled cows, and survivors.

\begin{tabular}{|c|c|c|c|c|c|c|c|c|c|}
\hline \multirow[b]{2}{*}{ Lactation } & \multicolumn{3}{|c|}{$\begin{array}{c}\text { Cows initiating each } \\
\text { lactation }\end{array}$} & \multicolumn{3}{|c|}{ Culled animals } & \multicolumn{3}{|c|}{ Surviving animals } \\
\hline & $\mathrm{N}$ & Mean & SD & $\mathrm{N}$ & Mean & SD & $\mathrm{N}$ & Mean & SD \\
\hline First & 392,800 & 368 & 104 & 66,232 & 386 & 154 & 326,568 & 365 & 90 \\
\hline Second & 326,568 & 328 & 122 & 114,427 & 279 & 159 & 212,141 & 355 & 85 \\
\hline Third & 212,141 & 313 & 128 & 98,964 & 270 & 157 & 113,177 & 351 & 77 \\
\hline Fourth & 113,177 & 278 & 131 & 80,498 & 256 & 144 & 32,679 & 334 & 61 \\
\hline Fifth & 32,679 & 235 & 131 & 31,613 & 235 & 131 & 1066 & 297 & 42 \\
\hline All & $1,077,365$ & 332 & 123 & 391,734 & 286 & 160 & 685,631 & 358 & 86 \\
\hline
\end{tabular}

essentially no cows now survive beyond 5 lactations. This result does not mean that the higher rates of culling observed now are associated with more profit. As Van Arendonk (1985) indicated, there must be an optimum length of HL and culling rate.

Another important trend is that farmers are milking their first-lactation cull cows much longer than before. First-lactation cows used to be culled at an average of $226 \mathrm{~d}$ (Table 4). The average time of culling for firstlactation cows in this study was $386 \mathrm{~d}$. The much higher level of production observed currently may allow these cows to remain profitable for a longer period, and thus delay the time of culling. The lactation length of firstlactation cows was more than $1 \mathrm{yr}$ for both survivors and nonsurvivors (Table 2). Cows with longer lactations have a greater number of opportunities for a successful breeding to occur, which may explain the lower culling rate of first-lactation cows currently observed (relative to $20 \mathrm{yr}$ ago). Breeders seem to be giving first-lactation cows more opportunity to become pregnant than cows of other ages. Such a practice would explain the longer lactation lengths for first-parity cows seen in Table 3.

The distribution of the lactation lengths differed between survivors and cull cows (Figure 1). Survivors had a distribution that was skewed to the right with most (90\%) of the cows producing milk even after $305 \mathrm{~d}$ postpartum. The mean lactation length was $358 \mathrm{~d}$ (Table 2 ). The cull cows were being removed from the herd at a uniform rate before $305 \mathrm{~d}$, then peaking, and declining at a steady rate. Seventy-eight percent of the cull cows had lactations of more than $305 \mathrm{~d}$. Ignoring the longer lactation lengths can cause problems in the analysis of PL. Truncating the productive period at 10 months-inmilk per lactation penalizes the survivors much more than the culled cows, giving a distorted record of the culling decisions. A comparison with historical data indicates that the duration of the lactations has lengthened, culling rates have increased and the age distribu-

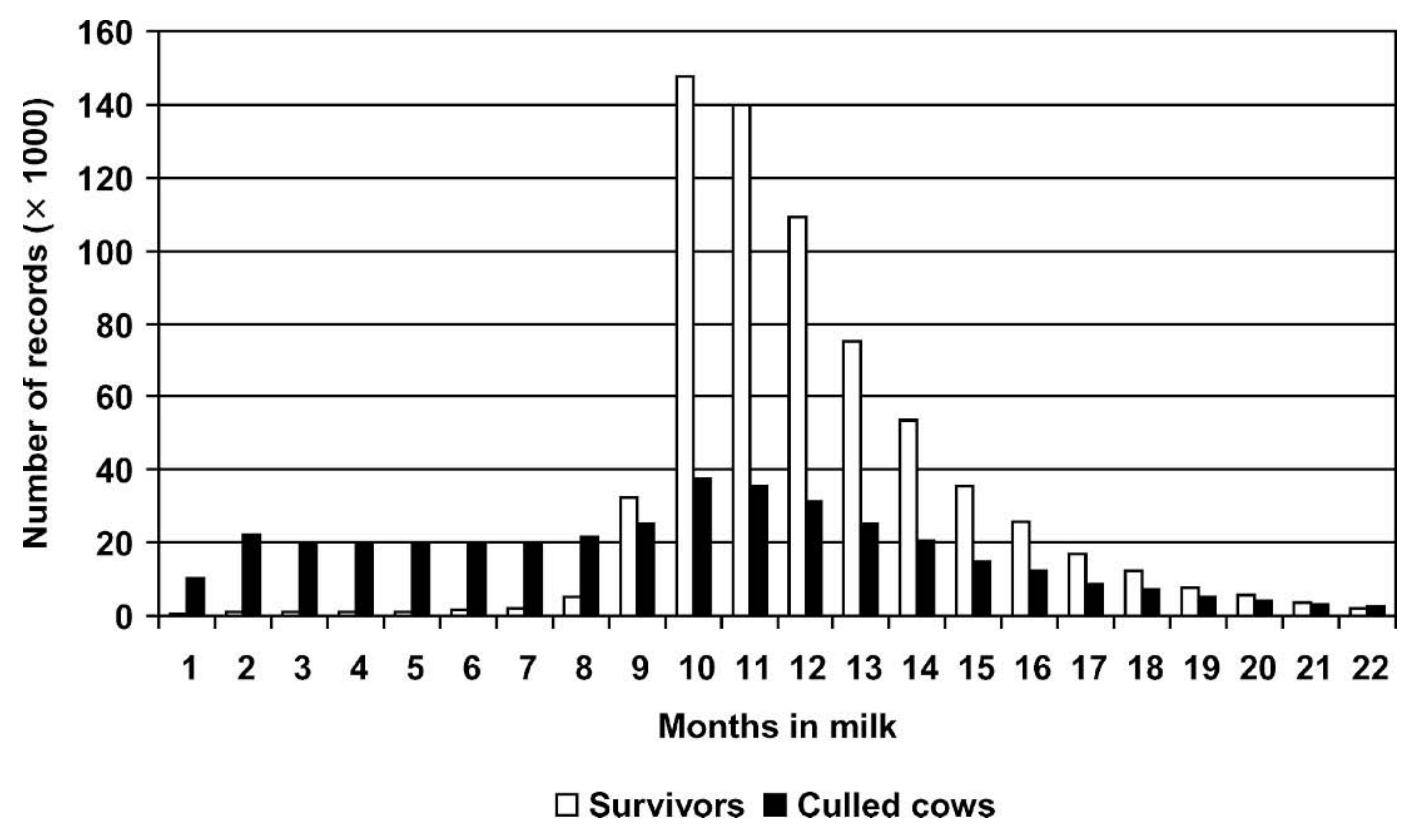

Figure 1. Distribution of months-in-milk for culled cows and survivors. 
Table 3. Risk (\%) of being culled per lactation.

\begin{tabular}{lll}
\hline & $\begin{array}{l}\text { Cows born } \\
\text { in the 1960s } \\
\text { and 1970s } \\
\text { (Nieuwhof et al., 1989) }\end{array}$ & $\begin{array}{l}\text { Cows born } \\
\text { in the 1990s } \\
\text { (current study) }\end{array}$ \\
Lactation & 21.8 & 16.9 \\
\hline First & 26.3 & 34.8 \\
Second & 29.3 & 46.7 \\
Third & 33.2 & 71.1 \\
Fourth & 37.1 & 96.7 \\
Fifth & & \\
\hline
\end{tabular}

tion of the herds has moved, resulting in herds consisting of younger cows.

\section{Heritability}

Heritability estimates for $\mathrm{PL}_{305}$, 305-d milk, fat, and protein yields, SCS, DO, final score, and 18 linear type traits are presented in Table 5. Posterior standard deviations of heritability were all \pm 0.01 . Heritability estimates varied slightly for the different measures of PL. The heritability estimate of 0.10 for the $\mathrm{PL}_{305}$ was slightly higher than 0.08 for $\mathrm{PL}_{500}$ and $\mathrm{PL}_{999}$ and 0.09 for HL (not shown). However, differences between those estimates were not significant. Those heritability estimates for PL were similar to the estimate of 0.085 for true stayability of Ducrocq et al. (1988) and 0.07 for true HL of Short and Lawlor (1992), but higher than the value of 0.05 for true stayability obtained by Hudson and VanVleck (1981), and 0.03 for true HL of Boldman et al. (1992). Heritability estimates for production and type traits were slightly higher but similar to those of Short and Lawlor (1992) and Weigel et al. (1998).

\section{Changes in Correlations}

Restricting the definition of PL to no more than 305 DIM per lactation altered its relationship with other traits. Phenotypically, the relationship of PL with production increased and the relationship with reproduction decreased as the period evaluated was lengthened. Most phenotypic correlations were consistent across the

Table 4. Average lactation length (d) of cows without a subsequent lactation.

\begin{tabular}{lllc}
\hline & $\begin{array}{l}\text { Cows born } \\
\text { in the 1960s } \\
\text { and 1970s } \\
\text { (Nieuwhof et al., 1989) }\end{array}$ & $\begin{array}{l}\text { Cows born } \\
\text { in the 1990s } \\
\text { (current study) }\end{array}$ & Difference \\
Lactation & 226 & 386 & +160 \\
\hline First & 236 & 279 & +43 \\
Second & 237 & 270 & +33 \\
Third & 237 & 256 & +19 \\
Fourth & 235 & 235 & 0 \\
\hline Fifth & & & \\
\hline
\end{tabular}

definitions of PL (not shown). Exceptions to this rule were correlations with production traits and with DO. Inasmuch as poor reproduction (and thus excessive DO) is one reason for culling, one would expect a negative relationship between PL and DO. However, increased DO also delays culling (due to the maintenance of higher milk production without pregnancy effects), and this factor would be expected to contribute a positive component to the correlation, a component that would have a larger impact with a longer period considered. The overall relationship between DO and longevity was found to be negative for all definitions of PL, but with decreasing magnitude as maximum recordable $\mathrm{PL}$ increased $\left(-0.24,-0.07\right.$, and -0.03 for $\mathrm{PL}_{305}, \mathrm{PL}_{500}$, and $\mathrm{PL}_{999}$, respectively). Increased production leads to an increased duration of presence in the herd, even among those cows that are to be culled, resulting in increasing phenotypic correlations between PL and production traits with increasing lactation length (i.e., 0.06, 0.13, and 0.14 for $\mathrm{PL}_{305}, \mathrm{PL}_{500}$, and $\mathrm{PL}_{999}$, respectively).

Genetic correlations (with posterior standard deviations ranging from 0.03 to 0.04 ) between the several measures of PL and the other traits are presented in Table 5. Several characteristics of the cow had a consistent relationship with PL regardless of the length of the productive period considered. Lower SCC, more capacious and better-attached udders, shorter teats, smaller body size, straighter legs, steeper foot angle, and higher overall conformation scores were consistently related to increased longevity. Other traits such as milk yield, DO, BCS, and dairy form, which are dependent upon the partitioning of nutrients, were strongly influenced by the length of the productive period evaluated. The 2 largest changes in genetic correlation with the different measures of PL were for reproduction and production traits. These 2 types of traits had an antagonistic relationship with each other. An increase in milk production was associated with an increase in DO; the genetic correlations were from 0.49 to 0.50 . As the length of the productive period measured increased, the correlation of PL with DO changed by 0.35 (-0.62 to -0.27$)$. Increased fertility is always desirable, but it is of critical importance when no credit is given to those cows that are still productive after 305 DIM. These changes can be explained partially by increase of average lactation length over time and the limit of 84 mo as used for PL. The average number of lactations within 84 mo of life decreases even though the total number of DIM may not decrease as much or none at all. With longer lactations, most cows milk for at least $305 \mathrm{~d}$. In this case, $\mathrm{PL}_{305}$ becomes the number of parities up to 84 mo of age $\times 305 \mathrm{~d}$. Assuming constant days dry and gestation length, longer lactations are due to longer DO. Consequently, for cows that survive to 
Table 5. Heritability and genetic correlation of productive life and herd life with 305-d milk, fat, and protein yields, SCS, days open, 18 linear type traits, and final score.

\begin{tabular}{|c|c|c|c|c|c|}
\hline \multirow[b]{3}{*}{ Traits } & \multicolumn{4}{|c|}{ Productive life } & \multirow[b]{3}{*}{ Herd life } \\
\hline & \multirow{2}{*}{$\frac{\text { Heritability }}{305-\mathrm{d} \text { limit }}$} & \multicolumn{3}{|c|}{ Genetic correlation } & \\
\hline & & 305-d limit & 500-d limit & 999-d limit & \\
\hline Productive life & 0.10 & $\ldots$ & $\ldots$ & $\ldots$ & $\ldots$ \\
\hline Milk & 0.40 & -0.11 & 0.08 & 0.14 & 0.04 \\
\hline Fat & 0.33 & -0.11 & 0.03 & 0.08 & 0.02 \\
\hline Protein & 0.35 & -0.12 & 0.05 & 0.10 & 0.02 \\
\hline SCS & 0.14 & -0.32 & -0.29 & -0.27 & -0.30 \\
\hline Days open & 0.07 & -0.62 & -0.36 & -0.27 & -0.36 \\
\hline Stature & 0.46 & -0.13 & -0.14 & -0.15 & -0.12 \\
\hline Strength & 0.33 & -0.20 & -0.23 & -0.23 & -0.21 \\
\hline Body depth & 0.41 & -0.29 & -0.28 & -0.27 & -0.26 \\
\hline Dairy form & 0.35 & -0.25 & -0.12 & -0.08 & -0.14 \\
\hline Rump angle & 0.38 & 0.03 & 0.03 & 0.03 & 0.03 \\
\hline Thurl width & 0.30 & -0.20 & -0.20 & -0.20 & -0.19 \\
\hline Rear legs side view & 0.19 & -0.10 & -0.07 & -0.05 & -0.09 \\
\hline Foot angle & 0.12 & 0.12 & 0.11 & 0.10 & 0.15 \\
\hline Fore udder attachment & 0.27 & 0.27 & 0.28 & 0.28 & 0.31 \\
\hline Rear udder height & 0.25 & 0.12 & 0.18 & 0.19 & 0.19 \\
\hline Rear udder width & 0.21 & 0.03 & 0.09 & 0.11 & 0.10 \\
\hline Udder cleft & 0.20 & 0.14 & 0.17 & 0.17 & 0.20 \\
\hline Udder depth & 0.42 & 0.37 & 0.35 & 0.33 & 0.38 \\
\hline Front teat placement & 0.32 & 0.03 & 0.04 & 0.04 & 0.06 \\
\hline Teat length & 0.33 & -0.11 & -0.12 & -0.12 & -0.12 \\
\hline Rear legs rear view & 0.12 & 0.14 & 0.13 & 0.12 & 0.15 \\
\hline Udder tilt & 0.20 & 0.07 & 0.08 & 0.08 & 0.11 \\
\hline BCS & 0.24 & 0.05 & -0.05 & -0.08 & -0.03 \\
\hline Final score & 0.28 & 0.13 & 0.18 & 0.18 & 0.21 \\
\hline
\end{tabular}

$84 \mathrm{mo}, \mathrm{PL}_{305}$ becomes an inverse function of DO. As more productive cows are generally allowed a higher voluntary waiting period (and thus longer DO), this may create a negative correlation of $\mathrm{PL}_{305}$ with production and explain the change in correlation between production and PL of various definitions. There may be several ways to avoid the strong dependency of DO and the PL measure currently used (i.e., $\mathrm{PL}_{305}$ ). The first one is to use a model that does not require an 84-mo limit. The survival model (Ducrocq, 1988) is one such model, although survival analysis required more demanding computations and may lose some accuracy by ignoring female relationships. The other possibility is to increase the credit in PL for longer lactations. The use of PL with some limit would decrease the influence of outliers, but the limit is going to be arbitrary. Another possibility is to eliminate any limit and just use HL. This trait has similar properties to $\mathrm{PL}_{500}$ and $\mathrm{PL}_{999}$, and the interpretation of $\mathrm{HL}$ is simple and less controversial.

The critical point is to select a PL measure that corresponds to the productive period under which the cows are exposed. Because most cows are milking for longer than 305 DIM, the productive period evaluated needs to include this additional time.

The relationships found within this study for dairy form and BCS with the different measures of PL sheds light on some important health issues of today's cows. Dairy form and BCS had a genetic correlation of -0.66 (not shown). A simple explanation is that more dairy character means a thinner cow if these 2 traits have a linear relationship. Farmers refer to dairy form as an indicator of a cow's "will" to milk. What is meant by this expression is that dairy form is not only a predictor of milk yield but also an indicator of a cow's propensity to convert body fat into metabolizable energy (Dechow et al., 2004a,b). In early lactation, high yielding cows will go into a negative energy balance because they cannot consume enough feed to meet their energy needs. The negative correlation $(-0.25)$ of dairy form with $\mathrm{PL}_{305}$ indicates that the cows that are forced to convert body reserves into energy put themselves at a higher risk level of being culled.

The negative correlation of dairy form with all measures of PL indicates that today's cows may be too effective at converting their body reserves into usable energy, whereby they are at an elevated risk level of being culled throughout their entire life. Dairy form and BCS are similar traits genetically; this study found a genetic correlation of -0.66 , whereas Dechow et al. (2004b) reported -0.72 , and Dechow et al. (2004c) reported -0.74 . Understanding the relationship that dairy form has with health and fertility traits of cows can be aided by a review of its relationship with BCS. Lassen et al. 
Table 6. Weights and maximum reliabilities $\left(\mathrm{r}^{2}\right)$ for indirect prediction of productive life and herd life.

\begin{tabular}{|c|c|c|c|c|}
\hline \multirow[b]{2}{*}{ Traits } & \multicolumn{3}{|c|}{ Productive life } & \multirow[b]{2}{*}{ Herd life } \\
\hline & 305-d limit & 500-d limit & 999-d limit & \\
\hline \multicolumn{5}{|l|}{ Weights } \\
\hline Milk & 0.28 & 0.31 & 0.32 & 0.29 \\
\hline Fat & 0.11 & 0.11 & 0.12 & 0.12 \\
\hline Protein & 0.00 & 0.04 & 0.05 & 0.05 \\
\hline SCS & -0.09 & -0.10 & -0.10 & -0.10 \\
\hline Days open & -0.85 & -0.55 & -0.48 & -0.54 \\
\hline Stature & -0.19 & -0.23 & -0.25 & -0.23 \\
\hline Strength & -0.30 & -0.40 & -0.40 & -0.45 \\
\hline Body depth & 0.38 & 0.51 & 0.52 & 0.52 \\
\hline Dairy form & -0.26 & -0.29 & -0.29 & -0.29 \\
\hline Rump angle & 0.05 & 0.05 & 0.05 & 0.06 \\
\hline Thurl width & -0.07 & -0.06 & -0.06 & -0.06 \\
\hline Rear legs side view & 0.05 & 0.05 & 0.05 & 0.05 \\
\hline Foot angle & 0.10 & 0.10 & 0.10 & 0.12 \\
\hline Fore udder attachment & -0.01 & -0.01 & -0.02 & -0.03 \\
\hline Rear udder height & -0.14 & -0.11 & -0.10 & -0.11 \\
\hline Rear udder width & 0.12 & 0.11 & 0.09 & 0.10 \\
\hline Udder cleft & 0.03 & 0.05 & 0.05 & 0.06 \\
\hline Udder depth & 0.20 & 0.25 & 0.26 & 0.25 \\
\hline Front teat placement & -0.12 & -0.12 & -0.13 & -0.13 \\
\hline Teat length & 0.00 & 0.00 & 0.00 & 0.00 \\
\hline Rear legs rear view & 0.03 & 0.06 & 0.06 & 0.05 \\
\hline Udder tilt & -0.09 & -0.10 & -0.10 & -0.09 \\
\hline BCS & 0.14 & 0.15 & 0.15 & 0.12 \\
\hline Final score & 0.25 & 0.23 & 0.23 & 0.27 \\
\hline $\begin{array}{l}\text { Maximum reliability } \\
\mathrm{r}^{2}\end{array}$ & 0.69 & 0.57 & 0.55 & 0.55 \\
\hline
\end{tabular}

(2003) noted that BCS could be used as a management tool to estimate energy balance at specific periods of a lactation or in a breeding program as an indicator of energy balance. They referred to BCS as "a subjective method of assessing the amount of metabolizable energy stored in fat and muscle." Rogers et al. (1999) found a genetic correlation of 0.73 between dairy form measured in the United States and disease other than mastitis measured in Denmark. Dechow et al. (2004c) did a follow up study with Danish and US data and found that dairy form had a stronger correlation with disease incidence than did BCS when both traits were measured by US classifiers. Correlations between BCS and disease tended to be nonsignificant when adjusted for dairy form whereas genetic correlation estimates between dairy form and disease were not reduced significantly by adjustment for BCS. They hypothesized that the relationship between both dairy form and BCS with metabolic and digestive diseases was likely due to differences in early lactation negative energy balance. Dechow et al. (2004a) reported that the phenotypic scores of dairy form and BCS closely followed the cow's lactation curve but in opposite directions. This suggests that both traits are visual measures of fat (energy reserves). Additionally, cows that are genetically inclined to have a high dairy form score (high angularity) at calving are likely to have the most change in dairy form during the first 2 mo of lactation. This means that cows that are genetically predisposed to score higher on dairy form will appear even sharper, more angular, and thinner at the peak of lactation than the other cows. In another study of US data, Dechow et al. (2004b) reported that dairy form was more highly correlated with both production and fertility than was BCS. The importance of dairy form as an indicator trait of potential changes in energy balance is further illustrated by the fact that it explains important variation in fertility above and beyond its association with production. It appears that dairy form may be a better indicator of potential changes in energy reserves than BCS. Dechow et al. (2004c) explained that BCS reflects variation in fat deposition among cows. Dairy form, as it is currently evaluated, may be more highly correlated with differences in total internal and external body fat than BCS. Whereas dairy form looks towards a future event, i.e., it is a predictor of a cow's ability to convert body fat into energy, BCS measures a current state, how much fat does the cow carry at the moment when the observation is made. The phenotypic and environmental correlations between BCS and PL with any definitions were not significantly different from zero $(-0.02$ to 0.00$)$.

Fatter cows have lower risk of being culled when a shorter time period is evaluated and a higher risk of being culled over a longer period. Over the entire life- 
Table 7. Weights and maximum reliabilities $\left(\mathrm{r}^{2}\right)$ for indirect prediction of productive life and herd life for 10 selected traits.

\begin{tabular}{|c|c|c|c|c|}
\hline \multirow[b]{2}{*}{ Traits } & \multicolumn{3}{|c|}{ Productive life } & \multirow[b]{2}{*}{ Herd life } \\
\hline & 305-d limit & 500-d limit & 999-d limit & \\
\hline \multicolumn{5}{|l|}{ Weights } \\
\hline Milk & 0.21 & 0.24 & 0.26 & 0.24 \\
\hline Fat & 0.09 & 0.11 & 0.11 & 0.11 \\
\hline Protein & $\ldots$ & $\ldots$ & $\ldots$ & $\ldots$ \\
\hline SCS & -0.11 & -0.11 & -0.11 & -0.09 \\
\hline Days open & -0.82 & -0.51 & -0.43 & -0.52 \\
\hline Stature & -0.12 & -0.15 & -0.15 & -0.22 \\
\hline Strength & $\ldots$ & $\ldots$ & $\ldots$ & $\ldots$ \\
\hline Body depth & $\cdots$ & $\ldots$ & $\ldots$ & $\ldots$ \\
\hline Dairy form & $\ldots$ & $\cdots$ & $\cdots$ & $\cdots$ \\
\hline Rump angle & $\ldots$ & $\ldots$ & $\ldots$ & 0.06 \\
\hline Thurl width & -0.08 & -0.08 & -0.08 & $\ldots$ \\
\hline Rear legs side view & $\ldots$ & $\ldots$ & $\ldots$ & $\ldots$ \\
\hline Foot angle & $\ldots$ & $\ldots$ & $\ldots$ & $\ldots$ \\
\hline Fore udder attachment & $\ldots$ & $\ldots$ & $\ldots$ & $\ldots$ \\
\hline Rear udder height & $\ldots$ & $\ldots$ & $\ldots$ & -0.10 \\
\hline Rear udder width & $\ldots$ & $\ldots$ & $\ldots$ & $\ldots$ \\
\hline Udder cleft & $\ldots$ & $\ldots$ & $\ldots$ & $\ldots$ \\
\hline Udder depth & 0.18 & 0.21 & 0.21 & 0.22 \\
\hline Front teat placement & -0.09 & -0.10 & -0.10 & -0.12 \\
\hline Teat length & $\ldots$ & $\ldots$ & $\ldots$ & $\ldots$ \\
\hline Rear legs rear view & $\ldots$ & $\ldots$ & $\ldots$ & $\ldots$ \\
\hline Udder tilt & -0.08 & -0.08 & -0.08 & $\ldots$ \\
\hline BCS & & $\ldots$ & $\ldots$ & $\ldots$ \\
\hline Final score & 0.18 & 0.19 & 0.20 & 0.29 \\
\hline \multicolumn{5}{|l|}{ Maximum reliability } \\
\hline $\mathrm{r}^{2}$ & 0.65 & 0.51 & 0.49 & 0.50 \\
\hline
\end{tabular}

time of the cow, there appears to be no need to change a cow's propensity for getting fat. The genetic correlation between BCS and HL did not differ significantly from zero. Genetic correlations of BCS with DO and production were negative $(-0.26$ and -0.30 , respectively). As cows maintain more body reserves (become fatter), fertility improves (DO goes down), and production goes down. Therefore, as the length of the productive period lengthens, production gains in importance and reproduction declines in importance, BCS goes from having a positive relationship with PL to a negative relationship.

\section{Indirect Prediction of PL}

Formulas for an indirect prediction of PL from correlated traits were developed (Table 6). The weights for the other traits, with the exception of DO, strength, and body depth, to predict the various measures of PL were similar. The weights are partial regression coefficients, which are dependent upon the other traits in the analysis. The change in DO represents a real change in importance of this trait with the various measures of PL. The change in weights for strength and body depth is more of a reflection of several traits describing body size being analyzed together in a multivariate analysis. The changes in the weights of these 2 traits tend to cancel each other out rather than representing any true change in the relationship of body size with the different measures of PL.

The ability to predict PL decreased as the length of the productive period evaluated increased. This could be explained by the fact that one trait (DO) with a high relationship with PL dominates the prediction for the shorter productive periods. When using all 24 traits to predict genetic merits for PL, maximum reliabilities of $0.69,0.57,0.55$, and 0.55 were estimated for $\mathrm{PL}_{305}$, $\mathrm{PL}_{500}, \mathrm{PL}_{999}$, and HL, respectively.

Increasing the number of traits used to predict PL from 1 to 10 correlated traits increased the maximum reliability from 0.39 to 0.65 for $\mathrm{PL}_{305}$ and from (0.11 to $0.14)$ to $(0.49$ to 0.51$)$ for the other measures of PL (Table 7). The prediction equation using a reduced model with 10 traits in the current study is substantially different from the one obtained by Weigel et al. (1998). This result may be due to changes in genetic correlations over time or the additional traits (DO, SCS, udder tilt, BCS, and final score) available in this analysis.

Maximum reliabilities increased asymptotically (e.g., from 0.13 to 0.57 for $\mathrm{PL}_{500}$ ) as the number of selected traits went from 1 to all 24 traits. Improvement in the equation to predict PL by including more traits 
Table 8. Measures of lifetime performance from 2 periods.

\begin{tabular}{|c|c|c|c|c|}
\hline Measure & Current study & \multicolumn{3}{|c|}{ Short and Lawlor, 1992} \\
\hline Age at first calving, $d$ & 803 & & 836 & \\
\hline Herdlife from first calving, $d$ & 1042 & & 1097 & \\
\hline Actual DIM, d & 881 & $936^{3}$ & & $893^{4}$ \\
\hline Milk production per 305-d lactation, kg & 11,374 & & 8811 & \\
\hline Average milk production per day, $\mathrm{kg}^{1}$ & 37.3 & & 26.2 & \\
\hline Lifetime milk production, $\mathrm{kg}^{2}$ & 32,861 & $24,523^{3}$ & & $23,397^{4}$ \\
\hline Milk production per day of total life, $\mathrm{kg}$ & 17.8 & 12.6 & & $12.1^{4}$ \\
\hline
\end{tabular}

dramatically slowed after the inclusion of the sixth trait. The 10 most important traits for predicting $\mathrm{PL}_{500}$ were DO, milk, fat production, udder depth, stature, SCS, final score, teat placement, thurl width, and udder tilt (Table 7).

Improving profitability depends upon the environment, resources, management system, and economic values of the time. The goal is not necessarily to just lengthen the productive period of a cow but rather improve the overall efficiency. It is well documented that production levels have increased tremendously in the last $20 \mathrm{yr}$. However, perhaps less appreciated has been the improvement in lifetime production and production per day of life.

A comparison of lifetime productivity of today's cows with cows born 20 yr earlier can be made by looking at the results of Short and Lawlor (1992). They measured HL in the same way as the current study (Table 8). Age at first calving has decreased by $33 \mathrm{~d}$. A comparison of total HL favors the past generation of cows by $55 \mathrm{~d}$. In the current study, the mean for lifetime DIM is $881 \mathrm{~d}$, as measured by PL999. Unfortunately, Short and Lawlor (1992) did not report this value. However, if we take into account the difference in number of parities (3.4 vs. 2.8) and a dry period of $60 \mathrm{~d}$, then the difference in the productive period drops to $12 \mathrm{~d}$. This difference may even be less if we adjust for changes in the length of the dry period that have taken place over time (average number of dry days have decreased from 61 to $54 \mathrm{~d}$ during this period; T. J. Lawlor, personal communication, 2004). Even with the assumption that the largest change ( $55 \mathrm{~d}$ ) is correct, the increase in production that has occurred during this time more than compensates for the loss. The difference in lifetime production is $8338 \mathrm{~kg}$. Today's cows produce at a much higher level, resulting in more production per day and more total lifetime milk. In Table 8, we observed large increases in production with little increase in actual DIM. This supports the reported small correlation between production and total HL (Powell and VanRaden, 2003).
Lifetime production continues to increase because of large increases in production per day with little increase in number of days.

Even though the changes made to US Holsteins may be economically sound, it is important to take note of the biological changes that have also occurred. One of the ways that cows are able to achieve the higher production levels is by directing more of their body energy reserves into milk production. This accomplishment is also associated with more DO and a growing antagonism with productive periods of $305 \mathrm{~d}$ or less. Growing evidence indicates that the animal's ability to convert energy reserves to production is at the expense of their health (Dechow et al., 2004c). Therefore, it would appear that a positive weight on reproduction, negative weight on dairy form, and additional recording of health traits would need to accompany the selection for higher production levels.

It is essential that PL be correctly defined for the conditions under which the selection will take place. This is necessary in order to capture the true reasons behind the culling decisions of dairy cows. It is believed that the current restriction of 305 DIM per lactation, which is placed upon the length of the productive period being evaluated, is the primary cause for the large changes in the genetic correlations between PL and several traits related to production and reproduction that have been observed in recent years. Truncating the productive period to only $305 \mathrm{~d}$ penalizes the survivors much more than it does the culled cows, giving a distorted record of the culling decisions.

Weigel et al. (1998) calculated the genetic correlation between $\mathrm{PL}_{305}$ and HL as 0.985 . That means that all 4 measures of PL will rank animals similarly. Although HL has the appealing feature that it encompasses the entire lifetime of the cow, it also includes the dry period, which is an unproductive time period, and can vary over time or from cow to cow. Although $\mathrm{PL}_{999}$ encompasses the entire productive period of the cow, extremely long lactations may not give a true indication 
of the desirable characteristics of the cow. Therefore, $\mathrm{PL}_{500}$ has the advantage that it captures the complete productive period for most of the cows without any complications of extensively long lactations.

\section{CONCLUSIONS}

Using the measurement $\mathrm{PL}_{305}$ is expected to have caused some additional indirect selection emphasis to be placed upon fertility. This was reasonable in a situation where no information of fertility was available. Now the situation has changed. Genetic evaluations for daughter pregnancy rate were introduced in 2003, and complete lactation lengths are now being routinely recorded and stored, making it possible to utilize a longer productive period per lactation. Estimated genetic correlations of $\mathrm{PL}$ with other traits indicate that PL with a longer limit of lactation length has more desirable properties than $\mathrm{PL}_{305}$. Indirect predictors of PL can be obtained replacing $\mathrm{PL}_{305}$ by $\mathrm{PL}_{500}$ and updating the equation being used as the routine measurement of PL. In that case, more weight on fertility should be placed in the Total Merit Index because $\mathrm{PL}_{500}$ or HL puts relatively more emphasis on production.

\section{ACKNOWLEDGMENTS}

Financial support from Holstein Association USA Inc. is greatly appreciated. We are grateful to Melvin Tooker of USDA for providing the DHI data.

\section{REFERENCES}

Allaire, F. R., and J. P. Gibson. 1992. Genetic value of herd life adjusted for milk production. J. Dairy Sci. 75:1349-1356.

Boldman, K. G., A. E. Freeman, B. L. Harris, and A. L. Kuck. 1992. Prediction of sire transmitting abilities for herd life from transmitting abilities for linear type traits. J. Dairy Sci. 75:552-563.

Dechow, C. D., G. W. Rogers, L. Klei, and T. J. Lawlor. 2004a. Heritability and correlations for body condition score and dairy form within and across lactation and age. J. Dairy Sci. 87:717-728.

Dechow, C. D., G. W. Rogers, L. Klei, T. J. Lawlor, and P. M. VanRaden. 2004b. Body condition scores and dairy form evaluations as indicators of days open in US Holsteins. J. Dairy Sci. 87:35343541.

Dechow C. D., G. W. Rogers, U. Sander-Nielsen, L. Klei, T. J. Lawlor, J. S. Clay, A. E. Freeman, G. Abdel-Azim, A. Kuck, and S. Schnell. 2004c. Correlations among body condition score from various sources, dairy form, and cow health from the US and Denmark. J. Dairy Sci. 87:3526-3533.
Dekkers, J. C. M., L. K. Jairath, and B. H. Lawrence. 1994. Relationships between sire genetic evaluations for conformation and functional herd life of daughters. J. Dairy Sci. 77:844-854.

Ducrocq, V., R. L. Quaas, E. J. Pollak, and G. Casella. 1988. Length of productive life of dairy cows. 2. Variance component estimation and sire evaluation. J. Dairy Sci. 71:3071-3079.

Hudson, G. F. S., and L. D. Van Vleck. 1981. Relationship between production and stayability in Holstein cattle. J. Dairy Sci. 64:2246-2250.

Lassen, J., M. Hansen, M. K. Sorensen, G. P. Aamand, L. G. Christensen, and P. Madsen. 2003. Genetic relationship between body condition score, dairy character, mastitis, and diseases other than mastitis in first-parity Danish Holstein cows. J. Dairy Sci. 86:3730-3735.

Lawlor, T. J., S. Tsuruta, L. Klei, and I. Misztal. 2002. Use of a random regression model to investigate changes in genetic parameters over time. Proc. 7th World Congr. Genet. Appl. Livest. Prod., Montpellier, France. CD-ROM communication 17:06.

Misztal, I., S. Tsuruta, T. Strabel, B. Auvray, T. Druet, and D. H. Lee. 2002. BLUPF90 and related programs (BGF90). Proc. 7th World Congr. Genet. Appl. Livest. Prod., Montpellier, France. CD-ROM communication 28:07.

Nieuwhof, G. J., H. D. Norman, and F. N. Dickinson. 1989. Phenotypic trends in herdlife of dairy cows in the United States. J. Dairy Sci. 72:726-736.

Powell, R. L., and P. M. VanRaden. 2003. Correlation of longevity evaluation with other trait evaluations from 14 countries. Pages 15-19 in Proc. Interbull Annual Mtg., Beltsville, MD. Inter. Bull Eval. Serv. Bull. No. 30. Dept. Anim. Breeding and Genet., SLU, Uppsala, Sweden.

Rogers, G. W., G. Banos, and U. S. Nielsen. 1999. Genetic correlations among protein yield, productive life, and type traits from the United States and diseases other than mastitis from Denmark and Sweden. J. Dairy Sci. 82:1331-1338.

Short, T. H., and T. J. Lawlor. 1992. Genetic parameters of conformation traits, milk, and herd life in Holsteins. J. Dairy Sci. 75:1987-1998.

Smith, J. W., A. M. Chapa, L. O. Ely, and W. D. Gilson. 2002. Dairy Production and Management Benchmarks. The University of Georgia College of Agricultural and Environmental Sciences Cooperative Extension Service, Athens, GA.

Tsuruta, S., I. Misztal, and T. J. Lawlor. 2004. Genetic correlations among production, body size, udder and productive life traits over time in Holsteins. J. Dairy Sci. 87:1457-1468.

Van Arendonk, J. A. M. 1985. Studies on the replacement policies in dairy cattle. II. Optimum policy and influence of changes in production and prices. Livest. Prod. Sci. 13:101-121.

VanRaden, P. M. 2001. Methods to combine estimated breeding values obtained from separate sources. J. Dairy Sci. 84(E. Suppl.):E47-E55.

VanRaden, P. M. 2002. Selection of dairy cattle for lifetime profit. Proc. 7th World Congr. Genet. Appl. Livest. Prod., Montpellier, France. CD-ROM communication 29:127.

VanRaden, P. M., and E. J. H. Klaaskate. 1993. Genetic evaluation of length of productive life including predicted longevity of life cows. J. Dairy Sci. 76:2758-2764.

VanRaden, P. M., M. E. Tooker, A. H. Sanders, and G. R. Wiggans. 2003. Quality of data included in genetic evaluations for daughter pregnancy rate. J. Dairy Sci. 86(Suppl. 1):132.

Weigel, K. A., T. J. Lawlor, Jr., P. M. VanRaden, and G. R. Wiggans. 1998. Use of linear type and production data to supplement early predicted transmitting abilities for productive life. J. Dairy Sci. 81:2040-2044. 